\title{
Molnupiravir: a novel efficacious antiviral candidate to COVID-19
}

\author{
Molnupiravir: um novo candidato a antiviral eficaz para COVID-19 \\ Molnupiravir: un nuevo antiviral eficaz candidato a COVID-19
}

\begin{abstract}
An unknown pneumonia-like disease has emerged in Wuhan, China, in late 2019. It is later named as SARS-CoV-2 which cause COVID-19. This virus spreads easily due to high mobilization and its transmission through droplets or aerosol and fomite. The World Health Organization (WHO) then declared this disease as a global outbreak in March 2020. As the world faces the outbreak of SARS-CoV-2, many researchers race to find the most efficacious treatment for COVID-19. Until now, the most common treatments for COVID-19 were only symptomatic such as decongestant, corticosteroid, interleukin inhibitor, and existing antiviral. The researchers then develop a brand new antiviral that works efficiently to inhibit SARS-CoV-2 and might become prophylaxis. This disease is called Molnupiravir or EIDD-2801, a nucleotide analog which inhibits SARS-CoV-2 replication, resulting in damaged mRNA and lethal virions. Molnupiravir works to produce mutagenesis in RNA viruses and prevent the virus from spreading widely throughout the human body. However, this drug is still needed to undergo clinical trial phase three. In this article, we will discuss how Molnupiravir works and its efficacy compared to existing drugs. This review article aims to provide an update about novel efficacious antiviral for COVID-19, Molnupiravir.
\end{abstract}

Keywords: COVID-19; Treatment; Nucleotide analog; Molnupiravir.

\section{Resumo}

Uma doença semelhante à pneumonia desconhecida surgiu em Wuhan, China, no final de 2019. Mais tarde, foi denominada SARS-CoV-2, que causa COVID-19. Este vírus se espalha facilmente devido à alta mobilização e sua transmissão por meio de gotículas ou aerossóis e fômites. A Organização Mundial da Saúde (OMS) então declarou esta doença como um surto global em março de 2020. Enquanto o mundo enfrenta o surto de SARS-CoV-2, muitos 
pesquisadores correm para encontrar o tratamento mais eficaz para COVID-19. Até agora, os tratamentos mais comuns para COVID-19 eram apenas sintomáticos, como descongestionante, corticosteroide, inibidor de interleucina e antiviral existente. Os pesquisadores então desenvolveram um novo antiviral que funciona de forma eficiente para inibir a SARS-CoV-2 e pode se tornar profilaxia. Esta doença é chamada de Molnupiravir ou EIDD-2801, um análogo de nucleotídeo que inibe a replicação do SARS-CoV-2, resultando em mRNA danificado e virions letais. O molnupiravir atua na produção de mutagênese em vírus de RNA e evita que o vírus se espalhe amplamente por todo o corpo humano. No entanto, esse medicamento ainda é necessário para passar pela fase três do ensaio clínico. Neste artigo, discutiremos como o Molnupiravir funciona e sua eficácia em comparação com os medicamentos existentes. Este artigo de revisão tem como objetivo fornecer uma atualização sobre o novo antiviral eficaz para COVID-19, Molnupiravir.

Palavras-chave: COVID-19; Tratamento; Análogo de nucleotídeo; Molnupiravir.

\section{Resumen}

Una enfermedad desconocida similar a la neumonía ha surgido en Wuhan, China, a fines de 2019. Más tarde se la denomina SARS-CoV-2, que Una enfermedad desconocida similar a la neumonía ha surgido en Wuhan, China, a fines de 2019. Más tarde se la denomina SARS-CoV-2, que causa el COVID-19. Este virus se propaga fácilmente debido a la alta movilización y su transmisión a través de gotitas o aerosoles y fómites. La Organización Mundial de la Salud (OMS) luego declaró esta enfermedad como un brote global en marzo de 2020. Mientras el mundo enfrenta el brote de SARS-CoV-2, muchos investigadores compiten para encontrar el tratamiento más eficaz para COVID-19. Hasta ahora, los tratamientos más comunes para COVID-19 eran solo sintomáticos, como descongestionantes, corticosteroides, inhibidores de interleucina y antivirales existentes. Luego, los investigadores desarrollan un nuevo antiviral que funciona de manera eficiente para inhibir el SARS-CoV-2 y podría convertirse en profilaxis. Esta enfermedad se llama Molnupiravir o EIDD-2801, un análogo de nucleótido que inhibe la replicación del SARS-CoV2, lo que da como resultado un ARNm dañado y viriones letales. El molnupiravir actúa para producir mutagénesis en los virus de ARN y evita que el virus se propague ampliamente por todo el cuerpo humano. Sin embargo, este medicamento todavía es necesario para someterse a la fase tres del ensayo clínico. En este artículo, analizaremos cómo funciona el molnupiravir y su eficacia en comparación con los medicamentos existentes. Este artículo de revisión tiene como objetivo proporcionar una actualización sobre el nuevo antivírico eficaz para COVID-19, molnupiravir.

Palabras clave: COVID-19; Tratamiento, Análogo de nucleótidos; Molnupiravir.

\section{Introduction}

In late December 2019, a pneumonia outbreak rose in a wet market in Hubei, Wuhan, China. (Suteja et al., 2020) This outbreak later spread rapidly through droplets or aerosols and on 11 March 2020, World Health Organization declared a COVID-19 pandemic situation caused by SARS-CoV-2 (Suteja et al., 2020; WHO, 2020). This virus has 85\% similarity to its predecessor and is targeting Angiotensin-converting Enzyme 2 (ACE-2) that is overexpressed in lung and gastrointestinal (Majumder \& Minko, 2021; Petrosillo et al., 2020). SARS-CoV-2 has a spike protein (S) on its surface that will bind into ACE-2 via receptor binding-domain (RBD). This virus then releases its viral genome to be replicated in the ribosome of the host cell and produce RNA-dependent RNA Polymerase (RdRp). RdRp later will catalyze RNA synthesis and become the main role of SARS-CoV-2 replication (Gao et al., n.d.).

The symptoms vary from asymptomatic to common symptoms such as fever, cough, diarrhea, chest tightness, up to Acute Respiratory Distress Syndrome (ARDS). Up until now, no single treatment can effectively cure and prevent COVID-19. Most of the treatment only reduces symptoms and many antiviral drugs are still undergoing clinical phase. In this review article, we will discuss many kinds of COVID-19 treatment, especially the brand new antiviral called Molnupiravir and its effectiveness compared to existing medicine.

\section{Method}

This is a narrative review about efficacious and pharmacokinetic of Molnupiravir which include a study from 2020 and 2021. The keywords for this review are COVID-19, treatment, nucleotide analog, and Molnupiravir. 


\section{Previous Treatment}

SARS-CoV-2 is a beta coronavirus type which can be treated using antiviral and symptomatic drugs. In general, treatment and prevention of viral infection using antivirals were based on avoiding viral infiltration to host cells by inhibiting or suppressing the viral genome replication or preventing virus entering host cells (Majumder \& Minko, 2021). Some of antiviral that being used to treat COVID-19 were Lopinavir/Ritonavir combination, Oseltamivir, Favipiravir, Ribavirin, and Remdesivir (Joshi et al., 2021; Majumder \& Minko, 2021; Yousefifard et al., 2020). Vaccine is the most popular treatment to prevent viral infection by injecting viral particles to priming the immune system in order to create antibodies against the virus (Majumder \& Minko, 2021). The most common vaccines that have been used widely against SARS-CoV-2 were protein subunit vaccine, viral vector vaccine, and mRNA based vaccine (Kaur \& Gupta, 2020). Besides antiviral and vaccine, direct injection of the antiviral antibodies from blood plasma of recovered patients to infected patients may reduce mortality rate. Lastly, there were several drugs used to treat the lung damage and respiratory distress caused by viral infection (Majumder \& Minko, 2021).

\section{Molnupiravir Mechanism of Action}

Molnupiravir or EIDD-2801 is a prodrug which contains a $\beta$-D-N4-hydroxycytidine (NHC) as its active form in blood plasma (Kabinger et al., 2021; Robson et al., 2020). The mechanism of action of molnupiravir divided into incorporation and mutagenesis (Kabinger et al., 2021). Molnupiravir acts as a nucleoside analog, which will incorporate negative sRNA which leads to mispair of positive sRNA products (Painter et al., 2021; Robson et al., 2020). This process will produce lethal mutagenesis or inactivated virus (Robson et al., 2020). (See Figure 1, next). 
Figure 1. Mechanism of Action of Molnupiravir.

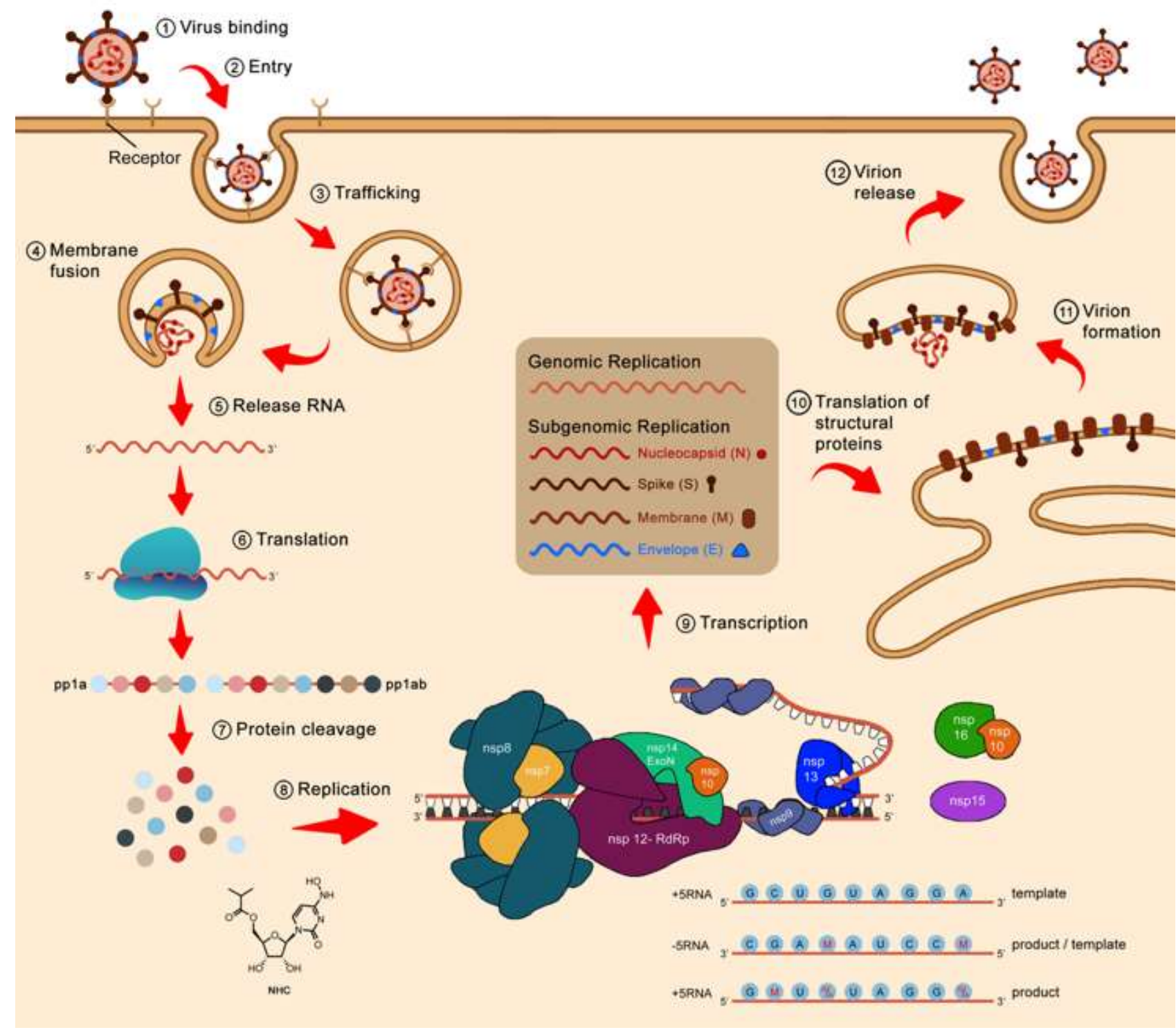

Source: Authors.

As seen in the figure, SARS-CoV-2 binds to ACE-2 receptors on epithelial cells of the respiratory tract using receptor-binding domain (RBD) of spike protein on the surface of the coronavirus (Majumder \& Minko, 2021). The viral genome then release into cells plasma and undergo translation of ORF1a and ORF1b resulting polyproteins pp1a and pp1b which will processed to become non-structural proteins (nsps) to help viral replication and transcription (V'kovski et al., 2020). These nsps will form nsp12-nsp7-nsp8 complex or called RdRp for nucleotide polymerization. This complex then creates a template of negative sRNA from positive sRNA. When the template has formed, the active form of Molnupiravir (NHC) will do the incorporation step, which the drugs will bind to the sRNA template because the RdRp tends to incorporate NHC instead of cyanine or uracil (Kabinger et al., 2021). Later when it is replicated into positive RNA by RdRp, the product will contain NHC and lead to mutation or error catastrophe, resulting a non-functional RNA (Kabinger et al., 2021). Besides the replication of viral RNA, the nsp12-nsp7-nsp8 complex also does the proofreading system (Agostini et al., 2018; Kirchdoerfer \& Ward, 2019). The nsp8 subunit will bind to nsp14 which contains CoV proofreading 3'-5' exoribonuclease 
(ExoN). ExoN can detect transcription error and fix it by removing the misincorporated nucleotides from the RNA chain (Kabinger et al., 2021). However, Molnupiravir will become 'invisible' or undetected as errors by ExoN because of its steadiness of Molnupiravir-Guanine and Molnupiravir-Adenine base pairs. Molnupiravir does not induce the reverse of RdRp, which will activate the RNA 3' end to the proofreading exonuclease (Kabinger et al., 2021). This mechanism will lead to mutagenesis and produce lethal virions.

\section{Current Clinical Trial}

Up until now, Molnupiravir has undergone clinical trial phase 2a to evaluate its tolerability, safety, and efficacy to treat SARS-CoV-2 and in progress to clinical trial phase 3 (ClinicalTrials.gov NCT04405570) . In phase 2a, a number of participants aged 18 years old were given single oral doses from 50 to 1,600 mg Molnupiravir and some were given placebo. Other participants were given twice-daily doses ranging from 50 to $800 \mathrm{mg}$ for approximately 5 days. The participants were observed for 14 days after completing the doses. This clinical trial has concluded that Molnupiravir is well tolerated and has a high potential to become antiviral treatment for SARS-CoV-2 as it has proven to have a high efficacy. This brand new drug also remarkably reduced viral shedding time, viral clearance time, and viral RNA reduction time. It has been shown that after four days of treatment, the amount of infectious virus decreased significantly and almost none in participants received 400 or $800 \mathrm{mg}$ molnupiravir (Painter et al., 2021).

Molnupiravir clearance through urine is increased from first administered to 24 hours postdose. Molnupiravir is absorbed immediately in blood plasma but absorbed slower if consumed after meal. However, there were no significant differences between administered before or after meals. Some participants had experienced mild adverse effects such as headache and diarrhea (Painter et al., 2021). Clearance time of viral RNA in day 3 until 28 was significantly decrease in participants taking $800 \mathrm{mg}$ Molnupiravir twice a day (Fischer et al., 2021). The average day of viral load clearance is at day five after first administered (Fischer et al., 2021).

In India, this drug has come into clinical trial phase 3 with 1218 participants with mild COVID-19. They were given Molnupiravir capsules $800 \mathrm{mg}$ twice a day for 5 days. As the result, patients taken Molnupiravir has lower hospital admissions rate after 14 days of observations (Fischer et al., 2021). There were no mortality and mostly patients experienced nausea, headache, and diarrhea as drugs adverse effect. These findings were similar to previous clinical trials (Fischer et al., 2021). Furthermore, Molnupiravir will undergo clinical trials for its efficacy as prophylaxis to COVID-19 with dose

\section{Comparison to Other Antiviral}

Compared to existing antiviral for SARS-CoV-2 treatment, Remdesivir, which has been approved by FDA, Molnupiravir were found more stable in its form when bind to mRNA template (Kabinger et al., 2021). Remdesivir act only as adenosine analog, while Molnupiravir can act both as adenosine and guanine analog (Majumder \& Minko, 2021).

WHO has suggest to repurposed antiviral drugs for COVID-19, as the existing drugs actually gave small, even no effect on hospitalized patients, indicated by mortality rate, length of hospital administered, and usage of ventilation (Consortium, 2021). However, beside effective drugs, early diagnosis in symptomatic and asymptomatic patients were important to reduce mortality and prevent further transmission (Consortium, 2021). Contact tracing, quarantine, and treatment by specific symptoms may improve patients' health and reduce mortality rate (Consortium, 2021). 


\section{Conclusions}

To sum up, Molnupiravir is one of the potential drugs for COVID-19 treatment and prophylaxis. Compared to existing drugs, Molnupiravir tends to be more stable and has minimal risk of resistance. Molnupiravir works as a nucleotide analog, which binds to sRNA positive template and causes mutagenesis on SARS-CoV-2 mRNA.

Molnupiravir or EIDD-2801 can avoid Exonuclease-N or SARS-CoV-2 proofreading thus preventing drug resistance. The virions produced after Molnupiravir bind to mRNA will be damaged and lethal. Molnupiravir has through clinical phase $2 \mathrm{a}$ with the result that Molnupiravir is well tolerated and has a high potential to become antiviral treatment for SARS-CoV-2. In India, Molnupiravir has through clinical trial phase 3 with promising results.

To date, Molnupiravir may cause nausea, headache, and diarrhea but no severe adverse effect has been recorded. Molnupiravir works well at doses 400 or $800 \mathrm{mg}$ twice a day given for 5 days. Molnupiravir is more stable than existing antiviral and likely become prophylaxis to SARS-CoV-2.

\section{Reference}

Agostini, M. L., Andres, E. L., Sims, A. C., Graham, R. L., Sheahan, T. P., Lu, X., Smith, E. C., Case, J. B., Feng, J. Y., Jordan, R., Ray, A. S., Cihlar, T., Siegel, D., Mackman, R. L., Clarke, M. O., Baric, R. S., \& Denison, M. R. (2018). Coronavirus susceptibility to the antiviral remdesivir (GS-5734) is mediated by the viral polymerase and the proofreading exoribonuclease. MBio, 9(2). https://doi.org/10.1128/MBIO.00221-18

Consortium, W. S. T. (2021). Repurposed Antiviral Drugs for Covid-19 — Interim WHO Solidarity Trial Results. New England Journal of Medicine, 384(6), 497-511. https://doi.org/10.1056/nejmoa2023184

Fischer, W., Eron, J. J., Holman, W., Cohen, M. S., Fang, L., Szewczyk, L. J., Sheahan, T. P., Baric, R., Mollan, K. R., Wolfe, C. R., Duke, E. R., Azizad, M. M., Borroto-Esoda, K., Wohl, D. A., Loftis, A. J., Alabanza, P., Lipansky, F., \& Painter, W. P. (2021). Molnupiravir, an Oral Antiviral Treatment for COVID19. MedRxiv: The Preprint Server for Health Sciences. https://doi.org/10.1101/2021.06.17.21258639

Gao, Y., Yan, L., Huang, Y., Liu, F., Zhao, Y., Cao, L., Wang, T., Sun, Q., Ming, Z., Zhang, L., Ge, J., Zheng, L., Zhang, Y., Wang, H., Zhu, Y., Zhu, C., Hu, T., Hua, T., Zhang, B., ... Rao, Z. (n.d.). Structure of the RNA-dependent RNA polymerase from COVID-19 virus. http://science.sciencemag.org/

Joshi, S., Parkar, J., Ansari, A., Vora, A., Talwar, D., Tiwaskar, M., Patil, S., \& Barkate, H. (2021). Role of favipiravir in the treatment of COVID-19. International Journal of Infectious Diseases, 102, 501-508. https://doi.org/10.1016/J.IJID.2020.10.069

Kabinger, F., Stiller, C., Schmitzová, J., Dienemann, C., Kokic, G., Hillen, H. S., Höbartner, C., \& Cramer, P. (2021). Mechanism of molnupiravir-induced SARS-CoV-2 mutagenesis. Nature Structural \& Molecular Biology. https://doi.org/10.1038/S41594-021-00651-0

Kaur, S. P., \& Gupta, V. (2020). COVID-19 Vaccine: A comprehensive status report. https://doi.org/10.1016/j.virusres.2020.198114

Kirchdoerfer, R. N., \& Ward, A. B. (2019). Structure of the SARS-CoV nsp12 polymerase bound to nsp7 and nsp8 co-factors. Nature Communications 2019 10:1, 10(1), 1-9. https://doi.org/10.1038/s41467-019-10280-3

Majumder, J., \& Minko, T. (2021). Recent Developments on Therapeutic and Diagnostic Approaches for COVID-19. The AAPS Journal, 23(14). https://doi.org/10.1208/s12248-020-00532-2

Painter, W. P., Holman, W., Bush, J. A., Almazedi, F., Malik, H., Eraut, N. C. J. E., Morin, M. J., Szewczyk, L. J., \& Painter, G. R. (2021). Human Safety, Tolerability, and Pharmacokinetics of Molnupiravir, a Novel Broad-Spectrum Oral Antiviral Agent with Activity against SARS-CoV-2. https://doi.org/10.1128/AAC.02428-20

Petrosillo, N., Viceconte, G., Ergonul, O., Ippolito, G., \& Petersen, E. (2020). COVID-19, SARS and MERS: are they closely related? In Clinical Microbiology and Infection (Vol. 26, Issue 6, pp. 729-734). Clin Microbiol Infect. https://doi.org/10.1016/j.cmi.2020.03.026

Robson, F., Shahed Khan, K., Le, T. K., Ment Paris, C., Demirbag, S., Barfuss, P., Rocchi, P., \& Ng, W.-L. (2020). Coronavirus RNA Proofreading: Molecular Basis and Therapeutic Targeting. Molecular Cell, 79, 710-727. https://doi.org/10.1016/j.molcel.2020.07.027

Suteja, R., Novianti, P., Dewi, K., Widiyanti, E., Wijayanti, I., K, C., \& Purnamasidhi, C. (2020). Migrant Workers of Indonesia: Transmission Channels of SARS-CoV-2 Amidst COVID-19 Pandemic in Indonesia. International Journal of Medical Reviews and Case Reports, 0, 1. https://doi.org/10.5455/ijmrcr.2020-05-197

V'kovski, P., Kratzel, A., Steiner, S., Stalder, H., \& Thiel, V. (2020). Coronavirus biology and replication: implications for SARS-CoV-2. Nature Reviews Microbiology 2020 19:3, 19(3), 155-170. https://doi.org/10.1038/s41579-020-00468-6

WHO. (2020). WHO Director-General's opening remarks at the media briefing on COVID-19 - 11 March 2020 . WHO Director General's Speeches, March, 4. https://www.who.int/director-general/speeches/detail/who-director-general-s-opening-remarks-at-the-media-briefing-on-covid-19---11-march-2020

Yousefifard, M., Zali, A., Ali, K. M., Neishaboori, A. M., Zarghi, A., Hosseini, M., \& Safari, S. (2020). Antiviral therapy in management of COVID-19: a systematic review on current evidence. Archives of Academic Emergency Medicine, 8(1), 1-9./pmc/articles/PMC7156260/ 